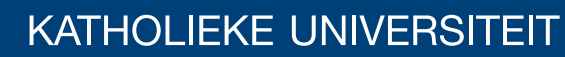 \\ LEUVEN
}

\section{Faculty of Business and Economics}

2 QNALH1 RQ]( [ FQMVINIRI] RDQL\&RQNDFW] \$Q( P SULFDQQYHMAJ DURQ

+ DQVI' HJU V-HIT DWRI,RDQQGRXI( UNNYRQ6 FKHGYQ

DEPARTMENT OF ACCOUNTANCY, FINANCE AND INSURANCE (AFI) 


\title{
On the Non-Exclusivity of Loan Contracts: An Empirical Investigation*
}

\author{
Hans Degryse \\ KU Leuven, Tilburg University, CEPR \& CESIfo \\ Naamsestraat 69 \\ 3000 Leuven, Belgium \\ h.degryse@uvt.nl \\ Vasso Ioannidou \\ Tilburg University \\ Department of Finance, CentER \& EBC \\ PO Box 90153 \\ 5000 LE Tilburg, The Netherlands \\ v.p.ioannidou@uvt.nl \\ Erik von Schedvin \\ Tilburg University \& Sveriges Riksbank \\ Department of Finance, CentER \& EBC \\ PO Box 90153 \\ 5000 LE Tilburg, The Netherlands \\ e.l.vonSchedvin@uvt.nl
}

February, 2012

\begin{abstract}
A string of theoretical papers shows that the non-exclusivity of credit contracts generates important negative contractual externalities. Employing a unique dataset, we identify how these externalities affect the supply of credit. Using internal information on a creditor's willingness to lend, we find that a creditor reduces its credit supply when a borrower obtains a loan at another creditor (an "outside loan”). Consistent with the theoretical literature, the effect is more pronounced the larger the outside loans and it is muted if the initial creditor's existing and future loans retain seniority over the outside loans and are secured with valuable collateral.
\end{abstract}

JEL Classification Numbers: G21, G34, L13, L14.

Keywords: non-exclusivity, contractual externalities, credit supply, debt seniority.

* The authors thank Viral Acharya, Andrea Attar, Bo Becker, Alberto Bennardo, Dion Bongaerts, Carlo Favero, Abe de Jong, Niklas Körling, Jose Liberti, Lars Norden, Steven Ongena, Marco Pagano, Mitch Petersen, Kasper Roszbach, Francesco Saita, Bogdan Stacescu, Phil Strahan, Hannes Wagner as well as conference and seminar participants at the 2012 American Finance Association Meetings (Chicago), 2011 European Finance Association Meetings (Stockholm), the 2011 CEPR-ESSFM Meeting (Gerzensee), the Norges Bank Workshop on Financial Intermediation (Oslo), the 3L Finance Workshop (Brussels), Bocconi University, DNB, Federal Reserve Bank of Philadelphia, University of Cyprus, University of Naples Federico II, RSM Rotterdam, and Tilburg University for helpful comments. The views expressed in this paper are solely the responsibility of the authors and should not be interpreted as reflecting the views of the Executive Board of the Sveriges Riksbank. 


\section{Introduction}

Financial contracts are non-exclusive. In credit markets, for example, borrowers cannot credibly commit to take loans from at most one creditor and creditors cannot completely prevent borrowers from taking credit from others. This is because contracts cannot be made fully contingent on loans from other creditors and in particular on future creditors who have not yet lent to the borrower. Such loans, however, could adversely affect a borrower's probability of repayment by exacerbating moral hazard and incentives for strategic default (e.g., Bizer and DeMarzo (1992) and Parlour and Rajan (2001)). The prospect of such loans is expected to worsen the borrower's access and terms of credit. When non-exclusivity is pervasive and cannot be contained, it could also lead to overborrowing, high rates of default, credit rationing, and market freezes. ${ }^{1}$

The non-exclusivity of credit contracts has played an important role in several financial crises such as the Latin-American debt crisis in the 1970s and the Asian crisis in the 1990s (Radelet and Sachs (1998) and Bisin and Guaitoli (2004)). Non-exclusivity has also been identified as an important factor behind the high interest rates and default rates in the consumer credit card market (Parlour and Rajan (2001)). More recently, the nonexclusivity in the credit derivatives market has played a central role in the financial crisis of 2007-2008. Acharya and Bisin (2010), for example, argue that the non-exclusivity of financial contracts coupled with the opacity of the over-the-counter (OTC) marketswhere credit default swaps (CDS) trade- played a central role in the current financial crisis by creating severe counterparty risk externalities. The risk that a party-in this case the seller of a CDS - might not be able to fulfill its future obligations depends largely on other, often subsequent, exposures. In a theoretical model, the authors show that more transparency on counterparty risk exposures in the OTC market could have helped the contracting parties internalize the externalities.

These insights are in line with parallel theoretical work on the role of the institutional framework on credit markets. Collateral and credit registries, for example, could help creditors protect their claims and thus dampen the impact of non-exclusivity on

\footnotetext{
${ }^{1}$ A stream of theoretical papers has studied the role of non-exclusivity in financial contracting. See, among others, Bizer and DeMarzo (1992), Kahn and Mookherjee (1998), Parlour and Rajan (2001), Bisin and Guaitoli (2004), Bennardo et al. (2009), and Attar et al. (2010) for a theoretical analysis of non-exclusivity in different game-theoretic settings.
} 
credit availability. Collateral, whose effective use is facilitated by a collateral registry, could mitigate moral hazard and incentives for strategic default (Holmström and Tirole (1997) and Parlour and Rajan (2001)). Credit registries could in some cases allow lenders to effectively employ ex-post punishment to enforce exclusivity or mitigate the resulting externalities by conditioning their terms on loans from others (Bennardo et al. (2009)).

Despite the substantial theoretical work on the impact of non-exclusivity on financial contracts and its role in major financial crises, up to now, no direct test of the impact of non-exclusivity on the functioning of financial markets was possible due to lack of adequate data. This paper aims to fill this void by employing a unique dataset containing information on a creditor's internal limit to the borrower both before and after a nonexclusivity event realizes. The internal limit indicates the maximum amount this creditor is willing to lend to a borrower; it represents the amount for which the bank's loan supply becomes vertical. Changes in the internal limit represent changes in loan supply. Hence, using this information, we investigate how a creditor's willingness to lend reacts after a firm with whom it held an exclusive relationship acquires loans from other creditors, which we refer to as outside loans. This would not be possible using data on the outstanding level of credit as this is an equilibrium outcome driven both by demand and supply factors whereas the theory concerns supply effects. The empirical analysis takes place in a setting where individual trades with other creditors can be observed and contractual features, such as collateral, can be employed more effectively.

Our empirical evidence is consistent with the theories on contractual externalities. We find that when a previously exclusive firm, obtains a loan from another bank, the firm's initial bank decreases its internal limit to the firm and it decreases it more the larger the size of the outside loans. We find that $\$ 1$ from another bank leads to a decrease in the initial bank's willingness to lend by 34 to 50 cents. As explained later, these estimates should be viewed as a lower bound on the effect of the negative externalities on credit availability and are not driven by reverse causality, omitted variable bias, or a reduced ability to extract rents. Consistent with the theoretical literature on contractual externalities, we also find that the initial bank's willingness to lend does not change when its existing and future loans are protected from the increased risk of default. In particular, we find that an outside loan does not trigger any change in the initial bank's willingness to 
lend if its existing and future loans retain seniority over the outside loans and the claims are secured with assets whose value is high and stable over time.

While there have not been direct investigations of the non-exclusivity externality using credit supply, several papers have investigated the reasons and the impact of establishing single versus multiple bank relationships. Some studies have found that older and larger firms and firms in countries with a lower degree of judicial efficiency are more likely to maintain multiple relationships (for an overview of the empirical studies see e.g., Degryse, Kim and Ongena (2009)). Some papers also find that firms that borrow from multiple banks are of lower quality (see, for example, Petersen and Rajan (1994)). Farinha and Santos (2002) follow the debt share of firms after initiating multiple relationships. They find that the bank with which the firm had an exclusive relationship loses quickly importance over time. While the findings are overall consistent with the presence of significant negative externalities stemming from the non-exclusivity of loan contracts, these studies do not identify the driving force behind these associations as they cannot disentangle demand and supply factors.

The remainder of the paper is organized as follows. Section 2 reviews the literature and develops two testable hypotheses. Section 3 presents the data and the institutional setting, while Section 4 describes our identification strategy. Section 5 discusses our results and various robustness checks and Section 6 concludes.

\section{Hypotheses on the Impact of Non-Exclusivity in Financial Contracting}

To structure our empirical analysis, we review the extant theoretical literature and summarize the key insights in two testable hypotheses. We also briefly review the institutional environment to better position our analysis into this literature. Finally, we also discuss alternative theories and their implications for our analysis.

As mentioned earlier, the inefficiencies resulting from the non-exclusivity of financial contracts are addressed in several theoretical papers, each highlighting different sources of the resulting externalities. Regardless of the model employed, additional outside lending imposes externalities on the existing lender by increasing the borrower's probability of default— the specific channel varies across models. 
In Bizer and DeMarzo (1992) and Bennardo et al. (2009) an outside loan imposes externalities on prior debt by exacerbating the borrower's moral hazard incentives. Everything else equal, a higher total indebtedness reduces the borrower's work effort leading to higher probability of default as in Holmström (1979) and Holmström and Tirole (1997). The outside loan imposes an externality on existing debt because the terms of the loan do not reflect the resulting devaluation of the existing debt. This is in contrast to a one-creditor environment where all effects are internalized by the sole creditor. Because new lenders do not pay for the externality they impose on existing debt, they can offer loans with more attractive terms. ${ }^{2}$ As a result borrowers cannot credibly commit to exclusivity. Recognizing the possibility of future outside loans, the initial creditor requires higher interest rates for any given loan (or put differently lends a smaller amount for any given interest rate) than it would if borrowers could commit to exclusivity. This in turn decreases the maximum amount of loans that the borrower can support.

In Parlour and Rajan (2001) and Bennardo et al. (2009) the non-exclusivity creates incentives for strategic defaults. The authors show that when multiple lenders can simultaneously offer loans to a borrower, incentives to overborrow with intentions to default could arise when borrowers can exempt a large fraction of their assets from bankruptcy proceedings. Everything else equal, these incentives increase in the total amount borrowed. Multiple lending in this setting creates a negative externality to all lenders as each loan increases the default risk of the others, which inhibits competition and undermines the availability and the terms of credit. When the externalities are pervasive, it could also result in credit rationing (Bennardo et al. (2009)).

Overall, the theories on contractual externalities predict that when a borrower obtains a loan from another creditor, the maximum amount that the borrower's initial

\footnotetext{
2 This sequential contracting creates incentives for opportunistic lending i.e., lenders have incentives to target the customers of other creditors with attractive offers at the expense of the initial lenders. These incentives arise because new lenders do not pay for the externality they impose on existing debt, while they can protect their own claims from the increased risk (through higher interest rates, for example).
} 
creditor will be willing to lend to this borrower should decrease and it should decrease more the larger the outside loan. ${ }^{3}$ This motivates our first testable hypothesis:

(H1) The theory on contractual externalities predicts that when a borrower obtains an outside loan, the maximum amount that the initial creditor will be willing to lend to the borrower will decrease and it will decrease more the larger the outside loan.

Creditors could employ several contractual features to mitigate the externalities resulting from the non-exclusivity of debt contracts. For example, they could use covenants that make loan terms contingent on future borrowing from other sources. Such covenants, however, are not widely used because they introduce other inefficiencies. ${ }^{4}$ Moreover, as Attar et al. (2010) point out, the ability of covenants to enforce exclusivity is bounded by limited liability; in some cases covenants may even aggravate the problem by creating incentives for opportunistic lending.

Another approach, first discussed in Fama and Miller (1972), is to prioritize debt (i.e., allow the borrower's existing debt to retain seniority over new loans). While prioritization avoids dilution of prior debt, Bizer and DeMarzo (1992) point out that this will not solve the externalities from sequential contracting if the higher levels of debt

\footnotetext{
${ }^{3}$ In Bizer and DeMarzo (1992), for example, a rational initial creditor anticipates the firm may seek additional loans up to the creditor's willingness to lend. These additional loans may be taken at the initial creditor or outside creditors. If the initial creditor correctly anticipated the externalities from outside loans in its pricing of prior debt, when an outside loan is obtained, the initial creditor's willingness to lend to the borrower should drop by an equal amount. A smaller drop is expected when the initial creditor's willingness to lend already partially reflects the anticipation of an outside loan.

${ }^{4}$ For example, with the use of debt covenants creditors could permit future borrowing only with the approval of existing creditors. This, however, would give veto power to existing creditors and open the door to hold-up problems (see, for example, Smith and Warner (1979) and Bizer and DeMarzo (1992)). Although hold-up problems could be mitigated if contracts could specify ex ante the exact circumstances under which borrowing would be allowed, designing fully state-contingent contracts is very difficult in practice and often prohibitively expensive. Making debt callable is an alternative mechanism. As pointed out in Bizer and DeMarzo (1992), this would solve the problem only if the call price equals the fair market value of debt in the absence of further borrowing. For this to be true the contract would either have to specify the fair market value ex ante, which is as complex as writing a fully state-contingent contract or base the call price on the ex post market price of debt, which again gives rise to hold-up problems.
} 
increase the incentives for moral hazard. Asking borrowers to pledge collateral could mitigate the increased incentive for moral hazard i.e., the fear of losing the pledged assets could induce high effort (Holmström and Tirole (1997)). ${ }^{5}$ According to Parlour and Rajan (2001), collateral could also be interpreted as a commitment to accept only one contract since it is by definition a non-exempt asset. ${ }^{6}$

A floating charge on the borrower's assets-a special form of collateral that carries over to future loans - could be an effective way to mitigate the contractual externalities as it allows the initial creditor's existing and future loans to retain seniority over future outside loans and at the same time curtails incentives for moral hazard and strategic default resulting from the higher levels of debt. ${ }^{7}$ The degree to which a floating charge will mitigate the externalities from outside loans depends positively on the value of the pledged assets and negatively on the volatility of their values (see, for example, Bennardo et al. (2009)). If, for example, the initial creditor's loss in the event of default is negligible, an outside loan will not impose any externalities to the existing lender and thus should not trigger any changes in its willingness lend. Regular collateral might not solve the externalities as it does not extend to future loans. This leads us to our second testable hypothesis:

(H2) The theory on contractual externalities predicts that an outside loan will not trigger a change in the initial creditor's willingness to lend if the initial creditor's existing and future claims are fully protected.

$\mathrm{H} 1$ and $\mathrm{H} 2$ are tested in the context of a modern banking system, where collateral and credit registries are operational, allowing lenders to mitigate the negative externalities

\footnotetext{
${ }^{5}$ Collateral is also motivated in the literature as a way to mitigate other ex post frictions such as difficulties in enforcing contracts (Banerjee and Newman (1993), Albuquerque and Hopenhayan (2004)) and costly state verification (e.g., Townsend (1979), Gale and Hellwig (1985), Williamson (1986), and Boyd and Smith (1994)).

${ }^{6}$ In the context of Attar et al. (2010) valuable collateral could be viewed as a way to sidestep limited liability (i.e., an alternative to using courts to enforce unlimited liability).

${ }^{7}$ Djankov et al. (2008) find that debt contracts secured with a floating charge are enforced more efficiently: they have higher recovery rates and shorter enforcement times.
} 
from the non-exclusivity of loan contracts. Everything, else equal, collateral registries facilitate the effective use of collateral (Haselmann et al. (2010)). Similarly, information sharing through credit registries could allow lenders to mitigate the negative externalities by conditioning their offers on future borrower behavior (see, for example, Bennardo et al. (2009)). ${ }^{8}$ Before turning to a detailed description of our data and the institutional framework we briefly discuss the predictions of alternative theories.

In addition to the literature on contractual externalities, alternative theories predict that multiple financing sources may actually decrease the borrower's probability of default, and thus increase the initial creditor's willingness to lend. (The outside loan and the initial bank's willingness to lend are complements.) This could happen, for example, if the outside loans facilitate a worthwhile project that the initial creditor could not finance alone (e.g., due to lack of sufficient liquidity as in Detragiache et al. (2001) or a too large exposure to the borrower as in Hertzberg et al. (2011)). ${ }^{9}$ In sharp contrast with H1, an outside loan in this case should increase the initial creditor's willingness to lend and it should increase it more the larger the outside loan. Hence, finding evidence consistent with H1 would not necessarily imply that these alternative theories are not at work. It would only imply that the theories on contractual externalities are at work and that they are sufficiently important to dominate empirically.

\footnotetext{
${ }^{8}$ Bennardo et al. (2009) point out that although information sharing is expected for the most part to mitigate the contractual externalities and expand the availability of credit it could also facilitate opportunistic lending if the value of the assets securing the existing debt is very volatile. See also Attar et al. (2010) on the limitations of covenants due to limited liability.

${ }^{9}$ Hertzberg et al. (2011) write that “a bank's optimal level of lending is ... due to the complementarity, increasing in the expected level of lending of another bank (p.386).” In addition, the willingness of another lender to extend credit to a borrower could also be perceived as a positive signal about the borrower's quality (e.g., Biais and Gollier (1997)). A signal from another lender could be particularly useful when the initial creditor is relatively uninformed or the prospects of the borrower are uncertain.
} 


\section{Data and Institutional Setting}

The paper makes use of a unique dataset containing detailed information on all corporate clients of one of the four largest banks in Sweden. ${ }^{10}$ The dataset contains detailed information on the contract and performance characteristics of all commercial loans between April 2002 and December 2008 as well as information about the borrowing firm. For each loan, we observe the origination and maturity dates, type of credit, loan amount, interest rate, fees, collateral as well as its subsequent performance. For each firm, we observe its industry, ownership structure, credit history, credit scores as well as the bank's internal limit to the firm—our key variable.

A bank's internal limit to a firm indicates the maximum amount that the bank is willing to lend to the firm. In economic terms, it indicates the amount for which the bank's loan supply becomes vertical. Hence, changes in the internal limit represent changes in loan supply. Loan officers are not allowed to grant loans that exceed the limit- they can only lend up to that amount. The internal limits are not directly communicated to firms as they do not involve a commitment from the bank. ${ }^{11}$ This is in sharp contrast to credit lines that are communicated and typically committed. ${ }^{12}$

A firm's internal limit is determined based on the firm's repayment ability. It can change during the so called "commitment review" meetings, where the exposure towards the firm is reevaluated. The meetings typically take place once a year on a date determined at the end of the previous meeting, but they can be moved to an earlier date if the firm's condition changes substantially (e.g., if the firm has new investment opportunities or the firm's condition deteriorates substantially). To determine a firm's internal limit, the committee makes use of both internal proprietary information (e.g., the loan officer's

\footnotetext{
10 The Swedish banking market is rather concentrated with the four largest banking groups accounting for around 80 percent of total banking assets. At the end of 2003, there were a total of 125 banks established in Sweden.

${ }^{11}$ Although the internal limit is not directly communicated, firms could indirectly learn their internal limits when they become binding. We return to this in the next section when we discuss our methodology.

12 The extant empirical literature has employed lines of credit to study several aspects of the credit markets such as credit constraints and default risk (see, for example, Sufi (2009), Jiménez et al. (2009), and Norden and Weber (2010)).
} 
evaluation report) as well as external public information. For example, through the main Swedish credit bureau, Upplysningscentralen (UC), the bank can observe whether the firm had recent repayment problems with other financial and non-financial institutions, the firm's external rating, the number, amount, and value of collateral on all outstanding bank loans as well as the number of loan applications. (The bank identities are not revealed.) This information is updated monthly and at any point in time the bank can obtain a report with historical data for the past twelve months. ${ }^{13}$

Hence, the Swedish institutional setting is such that banks know about past transactions with other creditors and can learn quickly about the borrowers' future borrowing. ${ }^{14}$ This provides us with a unique opportunity to study whether the theories on contractual externalities are at work by studying how the internal limit changes following the origination of loans from another bank. (These loans are not syndicated as otherwise the initial creditor can fully control the borrower's loan taking behavior.) As explained below, the bank's response is benchmarked relative to otherwise similar firms.

To obtain additional information about the firm, the bank dataset is merged with accounting data from the main credit bureau, UC, and information from the Swedish registration office, Bolagsverket. In particular, to determine a firm's age, the firm's date of registration is obtained from Bolagsverket. The available information from Bolagsverket allows us (as well as current or prospective lenders) to determine whether the firm has posted collateral on any of its outstanding loans and observe whether a lender has a floating charge on the firm. Data on the value and volatility of the floating charge assets are obtained from the bank dataset and the firm's accounting statements. ${ }^{15}$

\footnotetext{
${ }^{13}$ Information from the firm's annual accounting statements is also provided for corporations.

${ }^{14}$ In addition, the Swedish firms have few bank relationships (see, for example, Ongena and Smith (2000)). Non-exclusivity events are therefore part of this institutional setting, providing us with a unique laboratory to identify the role of the non-exclusivity externalities.

${ }^{15}$ The law determines the types of assets that can be pledged under a floating charge claim and the creditors' rights when a borrower defaults. As of 2004, a floating charge includes inventory, accounts receivable, equipment, real estate, financial assets such as cash, bank deposits, bonds, and stocks and can be invoked during bankruptcy like other collateral types (see Lag (2003:528) om Företagsinteckningar and Cerqueiro et al. (2011)). Banks typically combine a floating charge with a negative pledge clause to ensure the priority and value of the floating charge.
} 


\section{Methodology}

To test $\mathrm{H} 1$ and $\mathrm{H} 2$ we use a matching procedure. This procedure allows us to benchmark the adjustment in the internal limit of firms that obtain loans from other banks (the treatment group) with the adjustment in the internal limit of similar firms that do not obtain loans from other banks (the control group). Similar firms are obtained by matching on several firm characteristics at the time of the non-exclusivity event. By matching, we minimize the likelihood that other factors-besides the loans from other banks - are driving the observed adjustments. Next, we describe in detail how our treatment and control groups are defined as well as the firm characteristics that we match on.

\section{A. Treatment and Control Groups: Definition and Descriptive Statistics}

The treatment group consists of firms that enter the sample with an exclusive relationship with our bank and at some point during the sample period obtain a loan from another bank. (We define a relationship as exclusive if the firm borrows only from our bank for at least one year and we refer to the first loan(s) from other banks as "outside loan(s)”.) We identify whether a firm obtains an outside loan by comparing the bank's total outstanding loans to the firm with the firm's total bank debt reported in the firm's annual accounting statements. This allows us to once a year identify whether a firm borrows from another bank.

To investigate how the bank responds to an outside loan, we compare the internal limits around the time of the non-exclusivity event. Figure 1 illustrates our event window. Let $t^{\prime}$ indicate when the firm obtains a loan from another bank (i.e., when the nonexclusivity event takes place). Let $t_{0}$ indicate the time that the firm's first accounting statements following the non-exclusivity event are reported (i.e., this is when we can first observe the outside loan(s)) and $t_{0}-12$ to indicate the time of the firm's last accounting statements prior to the non-exclusivity event. Since the bank decides on the internal limit once a year-during its annual commitment review meeting - there are two possibilities about the timing of any reaction following the non-exclusivity event: either the meeting is held sometime between $t^{\prime}$ and $t_{0}$ or it is held sometime between $t_{0}$ and $t_{0}+12$. Hence, to 
evaluate how the bank reacts to the non-exclusivity event we study the change in bank's internal limit between $t_{0}-12$ and $t_{0}+12$ (i.e., the Limit $_{t_{0}+12}-$ Limit $_{t_{0}-12}$ of the treated firms). ${ }^{16}$

\section{[Insert Figure 1 about here]}

Due to the length of the event window and the available sample period, the treatment group contains firms that obtain a loan from another bank any time during the period 2004:04 to 2007:12. Given that data are available between 2002:04 and 2008:12, this allows us to verify that all firms enter the sample period with at least one year of an exclusive relationship with our bank and gives us one year after the last possible nonexclusivity event to observe the bank's limit at $t_{0}+12$. We omit firms with an internal limit lower than SEK 100,000 (this corresponds to around US\$14,000) at time $t_{0}-12$ since such small exposures are typically determined rather "mechanically" ${ }^{17}$ Similarly, we also omit non-exclusivity events with trivial amounts since externalities are expected to be small (if any). In particular, we require that the loan from the other bank is at least $1 \%$ of the firm's internal limit at $t_{0}-12$. Finally, since our goal is to investigate how the bank's loan supply reacts to the non-exclusivity event, we do not include firms whose internal limit at $t_{0}-12$ is binding (i.e., it is equal to their outstanding loans and unused credit lines at $t_{0}-12$ ) and thus can be driven by both demand and supply factors.

This yields a total of 991 treated firms. Figure 2 reports the number of treated firms in each year as a percentage of the firms with an exclusive lending relationship for which the internal limit is not binding. As can be observed in Figure 2, this percentage is fairly constant over time, ranging between $4.5 \%$ and $5.5 \%$, which is comparable to rates found in other studies (e.g., using data from Portugal and Bolivia, Farinha and Santos (2002) and Ioannidou and Ongena (2010) report rates of 4\% and 4.5\% per year, respectively).

\footnotetext{
${ }^{16}$ If the firm's relationship with the bank is terminated prior to $t_{0}+12$, we use the last observed limit between $t_{0}$ and $t_{0}+12$. This involves $6 \%$ of the treated firms. About $5 \%$ of Swedish firms have accounting periods longer than one year. We exclude those firms from our sample.

${ }^{17}$ Firms may always be able to hold a company credit card with a minimum amount. Such amounts are typically determined mechanically. Since we want to focus on strategic interactions, we do not include such automated decisions.
} 
[Insert Figure 2 about here]

In Table 1 we compare the characteristics of the treated firms relative to the "universe" of firms with our bank (i.e., all firms with an outstanding loan at our bank during the sample period). ${ }^{18}$ Compared to the "universe", the treated firms are faster growing firms with more tangible assets, lower cash flows, higher risk of default (e.g., higher default probabilities, worse credit ratings, and worse credit histories), larger limits relative to their assets, larger distance to limit, and higher interest rates on outstanding debt. ${ }^{19}$ Overall, these differences suggest that the treated firms are not a random draw of the population and highlight the importance of controlling as much as possible for firm characteristics that may influence the bank's internal limits as well as the probability of obtaining an outside loan. Our matching procedure is geared to meet this challenge.

\section{[Insert Table 1 about here]}

We begin by identifying a possible set of control firms. This includes firms that, like the treated firms, have an exclusive relationship with our bank at $t_{0}-12$ for at least one year, but unlike the treated firms retain this exclusive relationship for at least until the end of the event window, $t_{0}+12 .{ }^{20}$ Using information from the accounting statements, the credit registry, and the bank dataset we match the two groups with respect to several characteristics at the beginning of the event window, $t_{0}-12$. By matching we select the subsample of treated firms for which a similar control firm can be found and we benchmark

\footnotetext{
${ }^{18}$ For the treated firms, we report their characteristics just prior to the outside loan (i.e., at $t_{0}-12$ ). Hence, the number of observations is equal to the number of unique treated firms. For the "universe", we report their characteristics for the period they maintained a lending relationship with our bank, which yields 51,164 firm-year observations for 19,197 unique firms.

${ }^{19}$ Approximately $60 \%$ of the average treated and control firms' debt is bank debt. Non-bank debt consists almost entirely of trade credit for both the treated and the control firms as most of these firms do not have access to the bond market, a typical characteristic of small and medium sized enterprises with single banking relationships.

${ }^{20}$ In robustness checks, presented in Section 5.1.2, we also require that the control firm got a loan from the initial bank of similar size to the treated firm's outside loan between $t_{0}-12$ and $t_{0}$ (i.e., we require that during the same period the matched firms had a similar demand for loans).
} 
the bank's adjustment in the limit relative to the "matched control" firm over the same period (i.e., using $\left.\left(\text { Limit }_{t_{0}+12}-\text { Limit }_{t_{0}-12}\right)_{\text {treated }}-\left(\text { Limit }_{t_{0}+12}-\text { Limit }_{t_{0}-12}\right)_{\text {control }}\right)$.

The matching variables are selected with respect to factors that are acknowledged by the bank to be instrumental in its determination of the limits as well as variables that are identified in the literature to affect a firm's likelihood of obtaining an outside loan (i.e., the likelihood of replacing or adding a banking relationship) ${ }^{21}$ Hence, apart from matching on calendar-time, the identity of the initial bank, and key relationship characteristics through the way we define the eligible set of control firms, we also match on several firm characteristics. This includes publicly observable firm characteristics as well as characteristics that might only be observable to the initial bank (i.e., proprietary information gathered through past interactions).

The set of publicly observable characteristics includes industry, firm age, firm size, asset growth, tangible assets, cash flows, indicators of leverage such as total debt to total assets and total bank debt to total assets, external credit rating, and indicators of recent repayment problems. Some of these variables are observable (to us and other banks) through the firm's accounting statements. Others are observable through the credit registry. To control for bank proprietary information we also match on the firm's internal limit, the distance to limit (i.e., the difference between the firm's internal limit and its outstanding bank debt and committed but unused credit lines), and the interest rate on the most recently originated inside loan. ${ }^{22}$ The internal variables can be particularly useful in capturing relevant firm characteristics that are unobservable to us, but observable to the initial bank and thus key in the determination of the firm's internal limit and incentives to seek an outside loan. These internal variables are included only in our most conservative matching

21 See, for example, Detragiache et al. (2000), Ongena and Smith (2001), Farinha and Santos (2002), Berger et al. (2005), and Gopalan et al. (2011). Our bank was not involved in a merger during our sample period (see, for example, Sapienza (2002) and Degryse et al. (2011) for the effects of bank mergers on loan contracts and incentives to seek outside loans).

\footnotetext{
${ }^{22}$ When a firm has more than one recently originated loan outstanding at $t_{0}-12$, we use the highest interest rate among those loans. Similar results are obtained if we use the average interest rate or the bank's internal rating instead. Matching on the interest rate as opposed to ratings is preferred for the specifications presented in the tables because the ratings are sometimes missing.
} 
set (Match 2) as they come at the expense of degrees of freedom. Table 2 summarizes and defines our matching variables.

[Insert Table 2 about here]

The matching exercise yields 1,421 pairs corresponding to 350 treated firms and 1,170 control firms (Match 1$).{ }^{23}$ When we also match on the internal variables, the sample is reduced to 549 pairs with 207 treated firms and 507 control firms (Match 2). The descriptive statistics of the two "matched treated" groups are reported in Table 1 to facilitate comparison with respect to the 991 treated firms that we identified and the "universe" of firms with our bank. The treated firms for which a match can be found are overall better than their 991 treated counterparts. They are older firms, with more tangible assets, higher cash flows, higher leverage ratios, and a lower risk of default (e.g., lower default probabilities and perfect credit histories). They also have smaller outside loans relative to their total assets.

\section{B. Empirical Specifications}

Using the matched samples, we estimate the following baseline model:

$$
y=\alpha+\varepsilon,
$$

where $y$ is the difference in the adjustment of the internal limit between the "treated" firms and their matched "control” firms scaled by their respective total assets at $t_{0-12}$ (we refer to this variable as the bank's “standardized response”):

$$
y=\left[\frac{\text { Limit }_{t_{0}+12}-\text { Limit }_{t_{0}-12}}{\text { Total Assets }_{t_{0}-12}}\right]_{\text {treated }}-\left[\frac{\text { Limit }_{t_{0}+12}-\text { Limit }_{t_{0}-12}}{\text { Total Assets }_{t_{0}-12}}\right]_{\text {control }},
$$

\footnotetext{
${ }^{23}$ Each treated firm can be matched with more than one control firm. Similarly, a control firm could be a match for more than one treated firm. Treated firms without a match are dropped.
} 
The dependent variable is scaled by total assets to enhance comparability across firms of different size and we use total assets prior to the outside loans to avoid endogeneity problems. $\alpha$ is the constant term, and $\varepsilon$ is the error term in equation (1).

The model is estimated using OLS with the standard errors clustered at the treated firm-level. Because each treated firm can be matched with multiple firms, the point estimates are adjusted by weighting the observations by one over the number of matched control firms for each treated firm as in Ioannidou and Ongena (2010). ${ }^{24}$ A negative and statistically significant $\alpha$ indicates that banks decrease their loan supply when a firm originates a loan from another bank, consistent with the theories on contractual externalities and H1. It also implies the net empirical dominance of these theories over alternative theories that predict an increase in the initial creditor's willingness to lend.

To examine whether the bank's response varies with the size of the outside loan we augment equation (1) by adding the size of the outside loan scaled by total assets at $t_{0}-12$, OutsideLoan, as an explanatory variable ${ }^{25}$ :

$$
y=\alpha+\beta_{1} \text { OutsideLoan }+\varepsilon,
$$

The constant term, $\alpha$, measures the bank's response when the OutsideLoan is zero, while $\beta_{1}$ measures the degree to which the bank's response varies with the size of the outside loan. A negative $\beta_{1}$ and a zero or insignificant $\alpha$ would be consistent with H1.

To test H2, we augment equation (2) by introducing an interaction between the OutsideLoan and the degree to which the initial bank's claims are protected, $Z$ :

\footnotetext{
${ }^{24}$ As discussed later, the results are robust to using different estimation techniques (e.g., clustering the standard errors with respect to both the treated and the control firm as discussed in Cameron et al. (2006), Thompson (2006), and Petersen (2009) or using one observation per treated firm by randomly selecting one of the matched control firms-when the matching procedure yields multiples - and clustering the standard errors at the control firm-level).

${ }^{25}$ To avoid scaling the dependent and independent variables by the same variable we also estimated our model using $\left(\text { Limit }_{t_{0}+12} / \text { Limit }_{t_{0}-12}\right)_{\text {treated }}-\left(\text { Limit }_{t_{0}+12} / \text { Limit }_{t_{0}-12}\right)_{\text {control }}$ as an alternative dependent variable. All results were qualitatively and quantitatively very similar to those presented later in the paper and are available upon request. The same holds for results on equation (1) and (3).
} 


$$
y=\alpha+\beta_{1} \text { OutsideLoan }+\beta_{2} \text { OutsideLoan } \times Z+\beta_{3} Z+\varepsilon,
$$

The constant term, $\alpha$, measures the bank's response when the OutsideLoan is zero and its claims are not protected. $\beta_{1}$ measures the degree to which the bank's response varies with the OutsideLoan when its claims are not protected and $\beta_{2}$ measures the difference in the bank's response when its claims are protected. Finally, $\beta_{3}$ measures the bank's response when its claims are protected and the OutsideLoan is zero. A negative $\beta_{1}$, a positive $\beta_{2}$, and a zero or insignificant $\alpha$ and $\beta_{3}$ would be consistent with H2.

To capture the degree to which the bank's claims are protected, $Z$, we mainly employ three indicators: a dummy variable indicating whether the bank has a floating charge on the firm's assets (FloatingCharge) as well as two qualifying variables regarding the value of the floating charge assets (FloatingChargeValue) and the volatility of their values (FloatingChargeVolatility). The FloatingChargeValue is equal to the value of the floating charge assets as reported by the bank, scaled by committed bank debt at $t_{0}-12$ (i.e., outstanding debt plus unused credit lines). The FloatingChargeVolatility is equal to the volatility of earnings in the three years preceding $t_{0}-12$ divided by the firm's average assets over that period.

[Insert Table 3 about here]

Table 3 provides descriptive statistics on the characteristics of treated firms with and without a floating charge using our most conservative set of matching variables (Match 2). The two groups of firms are remarkably similar. The only statistically significant difference between them is with respect to age and asset growth: firms with a floating charge are younger with somewhat slower growth. With respect to other characteristics, they appear to be of a slightly lower quality (with less tangible assets, lower cash flows, a somewhat higher probability of default, and worse external ratings). These differences, however, are not statistically significant. 


\section{Results}

We now test our two hypotheses. We first document the bank's average reaction after the firm obtains a loan from another bank and the degree to which the bank's reaction depends on the size of the outside loan (H1). We then subject these results to several robustness checks with respect to possible endogeneity issues as well as possible alternative explanations for our findings and then examine the degree to which the bank's response is mitigated when its claims are protected $(\mathrm{H} 2)$.

\subsection{Non-Exclusivity Externalities and the Size of the Outside Loan: Test of H1}

\subsubsection{Main Results}

Table 4 reports our findings with respect to H1. Column (I) reports the bank's average response (i.e., equation (1)). Column (II) documents how the bank's response varies with the size of the outside loan (i.e., equation (2)). For both specifications we match the "treated" and "control" firms with respect to all the variables discussed above except for the bank-internal variables - the latter are added in corresponding specifications reported in Columns (III) and (IV). ${ }^{26}$ As mentioned earlier, matching on the internal variables allows us to better control for unobserved firm heterogeneity.

[Insert Table 4 about here]

Regardless of our set of matching variables, we find a negative and statistically significant constant term (i.e., the $\alpha$ in equation (1)), consistent with H1. In terms of magnitudes, we find that the "treated" firms' internal limit to total assets ratios drop on average by $6.6^{* * *}$ (Column (I)) and 6.2*** (Column (III)) percentage points more than the

\footnotetext{
${ }^{26}$ Theses specifications are estimated using OLS, weighting the observations by one over the number of control firms per treated firm and clustering the standard errors with respect to the treated firm. Similar results are obtained if the standard errors are clustered with respect to both the treated and the control firm. This procedure, however, does not allow for weighting the observations. Hence, we also estimate the model using one observation per treated firm by randomly selecting one of the matched control firms and clustering the standard errors with respect to the control firm. Results are again similar with those presented in Table 4.
} 
ratios of similar "control” firms. ${ }^{27}$ This amounts to a drop in the treated firms' average internal limit to total assets ratio of $15 \%$ and $14 \%$, respectively. All in all, these results are consistent with banks adjusting their internal limits downwards in view of the negative externalities resulting from the outside loans.

Consistent with this interpretation we also find that the bank decreases its internal limit more, the larger the outside loan. In terms of magnitudes, we find that the coefficient of the OutsideLoan (i.e., the outside loan to total assets ratio) in equation (2) ranges between $-0.335^{* * *}$ (Column (II)) and $-0.408^{* * *}$ (Column (IV)), depending upon the matching variables, whereas the constant term is not different from zero. In terms of economic significance, a 1-standard deviation increase in the OutsideLoan (which is around 0.25 in both matched samples) induces a drop in the limit to total assets by 0.084 to 0.11 (i.e., $-0.335 * 0.25$ in Column (II) and $-0.408 * 0.269$ in Column (IV)). This amounts to a drop in the average treated firm's limit to total assets ratio of $19.6 \%$ to $24.4 \%$, respectively. The estimated coefficients in Columns (II) and (IV) also imply that \$1 from another bank leads to a drop in the internal limit by 34 to 41 cents, respectively. ${ }^{28}$

All in all, our findings suggest that the initial bank decreases its loan supply once borrowers become non-exclusive and it decreases it more the larger the outside loans, consistent with the theories on contractual externalities. Our estimates should be viewed as a lower bound on the effect of the negative externalities on credit availability. There are several reasons for this. A firm's initial limit, for example, could already be lower reflecting the anticipation of an outside loan. Alternatively, contractual features (such as collateral and other covenants) may allow banks to mitigate the negative externalities for a sub-sample of firms, resulting in a lower average adjustment. Finally, the alternative theories which predict an increase in the limit might also be at work. Next, and before turning to H2, we discuss several robustness checks.

\footnotetext{
$27 * * *, * *, *$ indicate statistical significance at the 1,5 , and 10 percent levels, respectively.

${ }^{28}$ The change in the treated firm's limit at $t_{0}+12$ following a change in outside loan at $t_{0}$ is equal to $\beta_{1}$. This is obtained by multiplying both sides of equation (2) with the treated firm's total assets at $t_{0}$ and then taking the derivative with respect to the size of the outside loan. This is possible because the scaling variable, total assets at $t_{0}-12$, is not a function of the outside loan.
} 


\subsubsection{Robustness Checks: Alternative Explanations and Additional Controls}

We begin by investigating whether our findings are driven by alternative explanations such as reverse causality, omitted variable bias, and reduced ability to extract rents. For all cases, to conserve space we report results for our most conservative matching set, Match 2, which allows us to better control for unobserved firm heterogeneity.

\section{[Insert Table 5 about here]}

One possibility is that our findings are driven by reverse causality: a prior and gradual reduction in the internal limit has pushed the firm to another bank. To investigate this possibility we examine how the internal limit behaves in the period just prior to the non-exclusivity event i.e., $t_{0}-24$ and $t_{0}-12$. Re-estimating equations (1) and (2) using the earlier timing for our dependent variable, we find no evidence of reverse causality as both $\alpha$ and $\beta_{1}$ are close to zero and statistically insignificant (see Table 5, Columns (I)-(II)). Note further that failure to increase the limit and accommodate the growing needs of a firm could also be a reason to seek outside loans, but this explanation does not account for our findings as it does not predict a decrease in the internal limit. In the absence of any externalities, a firm's internal limit is not expected to change. ${ }^{29}$

A second possibility is that our findings are driven by an omitted variable bias. Firms with private information about deteriorating future performance may have incentives to secure additional credit before their bank and other potential creditors learn this. Hence, the decreases in the internal limit that we document could be adjustments to the news about their performance. (Our internal variables control for factors that are observable to the initial bank, and thus do not account for this possibility.) To investigate this possibility we re-estimate equations (1) and (2) for the sub-sample of high quality firms (with a probability of default $<2 \%$ and no recent repayment problems at $t_{0}-12$ ) whose condition did not deteriorate during the event window. As can be observed in Columns (III)-(IV) of

\footnotetext{
${ }^{29}$ This alternative explanation could have accounted for our findings if instead of the internal limit we were using the firm's outstanding debt at the initial bank, which often decreases over time as firms add or replace relationships (see Farinha and Santos (2002)).
} 
Table 5, the results are slightly stronger than those presented earlier in Table 4, suggesting that our findings are not driven by this alternative channel.

Next, we also investigate whether the observed decreases in the internal limit are driven by reduced ability to extract informational rents. Proprietary information gathered over the course of a bank-firm relationship might allow banks to extract rents from opaque firms that find it difficult to switch to other credit providers (see, for example, Sharpe (1990), Rajan (1992), and von Thadden (2004)). Although an outside loan would imply a reduced ability to extract rents, it is unclear that it should lead to a decrease in the bank's willingness to lend to the borrower. The initial bank might temporarily become more aggressive in an attempt to win the "switching" borrower back. (This is in fact consistent with evidence in Ioannidou and Ongena (2010) who find that subsequent loans to "switching” customers are priced even more competitively than the first loan.) Nevertheless, to investigate whether our findings are driven by a reduced ability to extract rents, we re-estimate equations (1) and (2) using the amount of fixed fees on lending products to total assets at $t_{0}-12$ as an indicator of possible rent extraction. As can be observed in Columns (V)-(VI) of Table 5 the results do not support this alternative explanation: our key coefficients remain unchanged, while the estimated coefficients of fees to total assets are statistically insignificant in both specifications.

Before turning to $\mathrm{H} 2$, we also investigate the robustness of our findings to a more stringent set of matching variables. In particular, to better control for investment opportunities, we further require that between $t_{0}-12$ and $t_{0}$ the matched control firm got an inside loan of similar size to the treated firm's outside loan (i.e., we require that both the treated and the matched control firms had similar demands for loans in the same period). As can be observed in Columns (VII)-(VIII) of Table 5, results are even stronger than those presented earlier - although the number of observations is substantially reduced. Finally, to better control for the strength of a bank-firm relationship, we also match on the length of the firms' relationships with the initial bank. As can be observed in Columns (IX)-(X), the results are similar with those presented earlier.

We now turn to H2, which we believe is also important for identification purposes as alternative explanations for our findings do not have predictions in line with H2. For example, if banks are reducing their limits because of reduced ability to extract rents (and 
not because of the negative externalities associated with the outside loans) as discussed above, their reaction is not expected to vary with the degree to which their claims are protected. A similar argument could be made for a possible reallocation of internal limits between borrowers in the presence of limit constraints at the bank level.

\subsection{Protection of the Initial Bank's Claims: Test of $\mathrm{H} 2$}

Table 6 presents our findings with respect to H2. We first estimate the model in equation (3) using the FloatingCharge dummy for our key explanatory variable $Z$. As mentioned earlier, a floating charge is a special form of collateral that automatically carries over to future loans and thus allows the bank's existing, but also future loans to retain seniority over outside loans. The bank's loans are also secured by the assets under the floating charge. The degree of protection depends on the value of the pledged assets as well as the volatility of their values. Hence, we also estimate the model using FloatingChargeValue and FloatingChargeVolatility for $Z$. Results with respect to other collateral types, are also presented to better understand the role of the floating charge.

\section{[Insert Table 6 about here]}

All specifications are estimated for both Match 1 (Columns I-IV) and Match 2 (Columns V-VIII). Results are qualitatively very similar between them. Hence, to conserve space we only discuss the results using Match 2- our most conservative and preferred set of matching variables. In Column (V), the coefficient of the OutsideLoan, $\beta_{1}$, is $0.496^{* * *}$, while the coefficient of the interaction term with the FloatingCharge, $\beta_{2}$, is $0.515^{* * *}$, resulting in a combined coefficient of 0.019 , which is neither economically nor statistically different from zero. Consistent with $\mathrm{H} 2$, we also find that the coefficient of the FloatingCharge, $\beta_{3}$, is close to zero and statistically insignificant. These findings suggest that when the initial bank's claims are protected through a floating charge, the bank does not react to the outside loan. Instead, when the bank's claims are not protected, $\$ 1$ from another bank leads to a drop in the internal limit by 50 cents.

Next, we study how the bank's response varies with the characteristics (value and volatility) of the floating charge assets. As can be observed in Column (VI) of Table 6, any 
given outside loan triggers a smaller reaction, the larger the value of the floating charge assets. The opposite is true for volatility. A floating charge on assets whose values are volatile triggers a larger reaction. In particular, the coefficient of the OutsideLoan, $\beta_{1}$, is $0.496^{* * *}$, while the coefficient of the interaction terms with value and volatility are $1.437 * * *$ and $-8.100 *$, respectively. In terms of economic significance, our estimates indicate that a 1-standard deviation increase in the FloatingChargeValue (i.e., by 0.266), decreases the bank's response to the OusideLoan by 0.38 (i.e., $1.437 * 0.266$ ). Similarly, a 1-standard deviation increase in the FloatingChargeVolatility (i.e., by 0.048 ), increases the bank's response to the OutsideLoan by 0.39 (i.e., $8.1 * 0.048) .{ }^{30}$

To further understand the role of the floating charge, we also investigate the bank's response when its claims are protected through other collateral types (this includes fixed charge claims, pledges and liens). Our indicator, OtherCollateral, is a dummy variable that equals one when the bank's existing debt is only secured with other types of collateral (whose value relative to the outstanding loan is greater or equal to $80 \%$ ), and it is equal to zero otherwise. Everything else equal, these other collateral types should be less effective as they do not necessarily allow the bank's future loans to retain seniority over outside loans and they do not automatically carry over to the bank's future loans. They could, however, help mitigate some of the externalities insofar as the fear of losing the pledged assets mitigates the increased moral hazard associated with the higher levels of debt.

Results presented in Columns (VII) of Table 6 suggest that this is not the case. The coefficient of the OutsideLoan, $\beta_{1}$, is $-0.377^{* *}$, while the coefficient of the interaction term, $\beta_{2}$, is 0.007 . Including the FloatingCharge and OtherCollateral variables in the same specification yields similar results. In particular, in Column (VIII) the coefficient of OutsideLoan*FloatingCharge is $0.500 * * *$ whereas the coefficient of OutsideLoan*OtherCollateral is -0.007 , suggesting that the presence of a floating charge mitigates the negative contractual externalities, while other collateral does not. All in all, these findings suggest that the explanatory power of the floating charge may rest on its ability to protect not only the bank’s current but also future loans.

\footnotetext{
${ }^{30}$ This finding is consistent with Bennardo et al. (2009) who argue that volatile collateral values magnify the negative contractual externalities.
} 


\section{Conclusions}

Credit contracts are non-exclusive. While a set of theoretical papers study the impacts of non-exclusivity on the initial creditor's behavior, up to now, no empirical study has directly investigated the impact of non-exclusivity on the initial creditor's willingness to lend. In this paper, we aim to fill this gap by employing a unique dataset that allows for the first time to directly investigate how a bank's willingness to lend changes when an exclusive borrower obtains loans from another bank. This would not be possible using data on the outstanding level of credit as this is an equilibrium outcome driven by both demand and supply factors.

Our findings are consistent with the theories on contractual externalities. We find that when a previously exclusive firm obtains a loan from another bank, the firm's initial bank decreases its internal limit to the firm and it decreases it more the larger the size of the outside loans. We further show that our findings are not driven by alternative explanations such as reverse causality, omitted variable bias, or a reduced ability to extract rents. Consistent with the theoretical literature on contractual externalities, we also find that the initial bank's willingness to lend does not change when its existing and future loans are protected from the increased risk of default. In particular, we find that an outside loan does not trigger any change in the initial bank's willingness to lend if its existing and future loans retain seniority over the outside loans and the claims are secured with assets whose value is high and stable over time.

Although our analysis focuses on credit markets, the insights drawn extend to other markets such as the insurance and credit default swaps markets, where the externalities resulting from the non-exclusivity of financial contracts have recently played a pivotal role in the current financial crisis. The collapse of AIG and Lehman Brothers has only highlighted the pressing need for an improved institutional framework that could help the involved parties to better evaluate and internalize the externalities. Consistent with the theoretical literature, our results highlight that information on counterparty exposures combined with contractual features, such as general collateral that extends to future exposures, could mitigate the externalities from counterparty risk. 


\section{References}

Acharya, V., and Bisin, A., 2010, Counterparty Risk Externality: Centralized versus OverThe-Counter Markets, mimeo, http:/papers.ssrn.com/sol3/ papers.cfm?abstract_id=1573355.

Albuquerque, R., and Hopenhayn, H.A., 2004, Optimal Lending Contracts and Firm Dynamics, Review of Economic Studies, 71, 285-315.

Attar, A., Campioni, E., and Piaser, G., 2006, Multiple Lending and Constrained Efficiency in the Credit Market, Contributions to Theoretical Economics 6(1), Article 7.

Attar, A., Casamatta, C., Chassagnon, A., and Decamps, J. P., 2010, Multiple Lenders, Strategic Default and the role of Debt Covenants, Working Paper.

Banerjee, A.V., and Newman, A. F., 1993, Occupational Choice and the Process of Development, Journal of Political Economy, 101, 274-298.

Bennardo, A., Pagano, M., and Piccolo, S., 2009, Multiple-Bank Lending, Creditor Rights and Information Sharing, CEPR DP7186.

Berger, A.N., Miller, N.H., Petersen, M.A., Rajan, R., and Stein, J.C., 2005. Does Function Follow Organizational Form? Evidence from the Lending Practices of Large and Small Banks, Journal of Financial Economics, 76, 2, 237-269.

Biais, B., and Gollier, C., 1997, Trade Credit and Credit Rationing, Review of Financial Studies, 10, 903-937.

Bisin, A., and Guaitoli, D., 2004, Moral Hazard and Nonexclusive Contracts, Rand Journal of Economics, 35, 2, 306-328.

Bizer, D. S., and DeMarzo, M., 1992, Sequential Banking, Journal of Political Economy 100(1), 41-61.

Boyd, J.H., and Smith, B.D., 1994, The Equilibrium Allocation of Investment Capital in the Presence of Adverse Selection and Costly State Verification, Economic Theory, 3, 427-451.

Cameron, C., Gelbach, J., and Miller, D., 2006, Robust Inference with Multi-Way Clustering, NBER Technical Working Paper no. 327. 
Cerqueiro, G., Ongena, S., and Roszbach, K., 2011, Collateralization, Bank Loan Rates and Monitoring: Evidence from a Natural Experiment, CentER Working Paper 2011-087.

Degryse, H., Kim, M., and Ongena, S., 2009, The Microeconometrics of Banking: Methods, Applications and Results, Oxford University Press.

Degryse, H., Masschelein, N., and Mitchell, J., 2011, Staying, Dropping or Switching: The Impacts of Bank Mergers on Small Firms, Review of Financial Studies, 24(4), 1102-1140.

Detragiache, E., Garella, P.G., and Guiso, L., 2000, Multiple versus Single Banking Relationships: Theory and Evidence, Journal of Finance, 55, 1133-1161.

Djankov, S., Hart, O., McCliesh, C., and Schleifer, A., 2008, Debt Enforcement around the World, Journal of Political Economy, 116, 1105-1149.

Fama, E., and Miller, M., 1972, The Theory of Finance, Hinsdale Ill., Dryden.

Farinha, L., A., and Santos, J. A., 2002, Switching from Single to Multiple Bank Lending Relationships: Determinants and Implications, Journal of Financial Intermediation, $11,124-151$

Gale, D., and Hellwig, M., 1985, Incentive-Compatible Debt Contracts: The One-Period Problem, Review of Economic Studies, 52, 647-663.

Gopalan, R., Udell, G., and Yerramilli, V., 2010, Why Do Firms Form New Banking Relationships?, forthcoming in Journal of Financial and Quantitative Analysis.

Haselmann, R., Pistor, K., and Vig, V., 2009, How Law Affects Lending, Review of Financial Studies, 23, 549-580.

Hertzberg, A., Liberti, J.M., and Paravisini, D., 2011, Public Information and Coordination: Evidence from a Credit Registry Expansion, Journal of Finance, 66, 379-412.

Holmström, B., 1979, Moral Hazard and Observability, Bell Journal of Economics, 10, 7491.

Holmström, B., and Tirole, J., 1997, Financial Intermediation, Loanable Funds, and the Real Sector, Quarterly Journal of Economics, 62, 663-691.

Ioannidou, V., and Ongena, S., 2010, Time for a Change: Loan Conditions and Bank Behavior when Firms Switch Banks, Journal of Finance, 65, 1847-1878. 
Jiménez, G. Z., López, J. A., and Saurina, J., 2009, Empirical Analysis of Corporate Credit Lines, Review of Financial Studies, 22, 5069-5098.

Kahn, C., and Mookherjee, D., 1998, Competition and Incentives with Nonexclusive Contracts, Rand Journal of Economics, 29, 443-465.

Ongena, S., and Smith, D., 2000, What Determines the Number of Bank Relationships? Cross-Country Evidence, Journal of Financial Intermediation, 9, 26-56.

Norden, L., and Weber, M., 2010, Credit line usage, checking account activity, and default risk of bank borrowers, Review of Financial Studies, 23, 3665-3699.

Parlour, C., and Rajan, U., 2001, Competition in Loan Contracts, American Economic Review, 91(5), 1311-1328.

Petersen, M., 2009, Estimating Standard Errors in Finance Panel Data Sets: Comparing Approaches, Review of Financial Studies, 22, 435-480.

Petersen, M., and Rajan, R., 1994, The Benefits of Lending Relationships: Evidence from Small Business Data, Journal of Finance, 49, 3-37.

Radelet, S., and Sachs, J., 1998, The Onset of the East Asian Financial Crisis, NBER Working Paper 6680.

Rajan, R., 1992, Insiders and Outsiders: The Choice between Informed and Arm's-Length Debt, Journal of Finance, 47, 1367-1400.

Sapienza, P., 2002, The Effects of Banking Mergers and Loan Contracts, Journal of Finance, 57, 329-367.

Sharpe, S.A., 1990, Asymmetric Information, Bank Lending and Implicit Contracts: A Stylized Model of Customer Relationships, Journal of Finance, 45, 1069-1087.

Smith, C.W. Jr., and Warner, J.B., 1979, On Financial Contracting: An Analysis of Bond Covenants, Journal of Financial Economics, 7, 117-161.

Sufi, A., 2009, Bank Lines of Credit in Corporate Finance: An Empirical Analysis, Review of Financial Studies, 22(3), 1057-1088.

Thompson, S., 2011, Simple Formulas for Standard Errors that Cluster by Both Firm and Time, Journal of Financial Economics, 99, 1-10.

Townsend, R.M., 1979, Optimal Contracts and Competitive Markets with Costly State Verification, Journal of Economic Theory, 21, 265-293. 
von Thadden, E.L., 2004, Asymmetric Information, Bank Lending, and Implicit Contracts: The Winner's Curse, Finance Research Letters, 1, 11-23.

Williamson, S.D., 1986, Costly Monitoring, Financial Intermediation and Equilibrium Credit Rationing, Journal of Monetary Economics, 18, 159-179. 
Figure 1: The Event Window

Firm obtains an outside loan

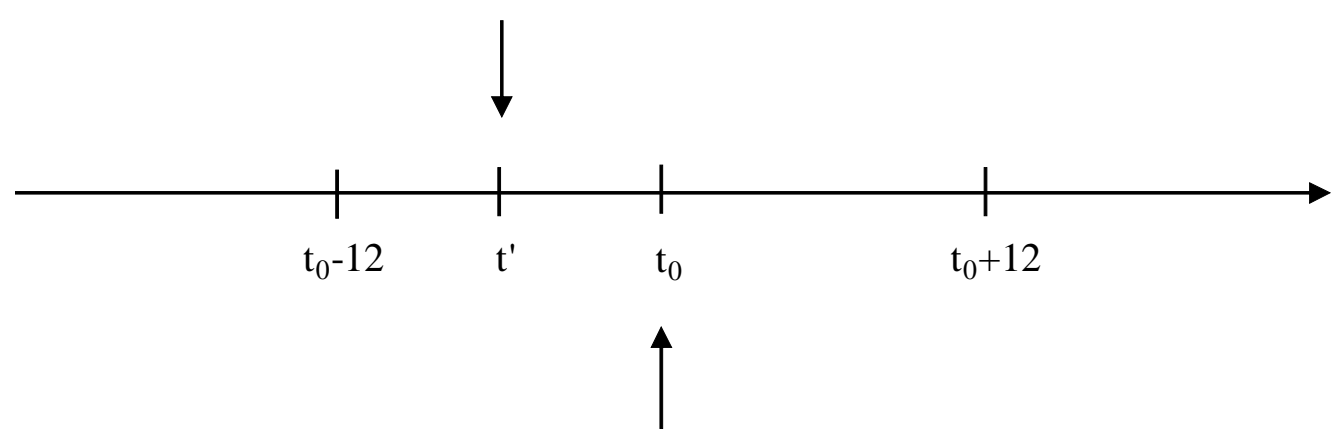

Outside loan is observed

Note. - This figure describes the event window in months. Firms enter the event window with an exclusive lending relationship with our bank. At time $t_{0}$ an outside loan, originated at $t^{\prime}$, is observed through the firm's accounting statements. The window $\left[t_{0}-12, t_{0}+12\right]$ captures the bank's response to an outside loan. 
Figure 2: Incidence of Non-Exclusivity Events Each Year

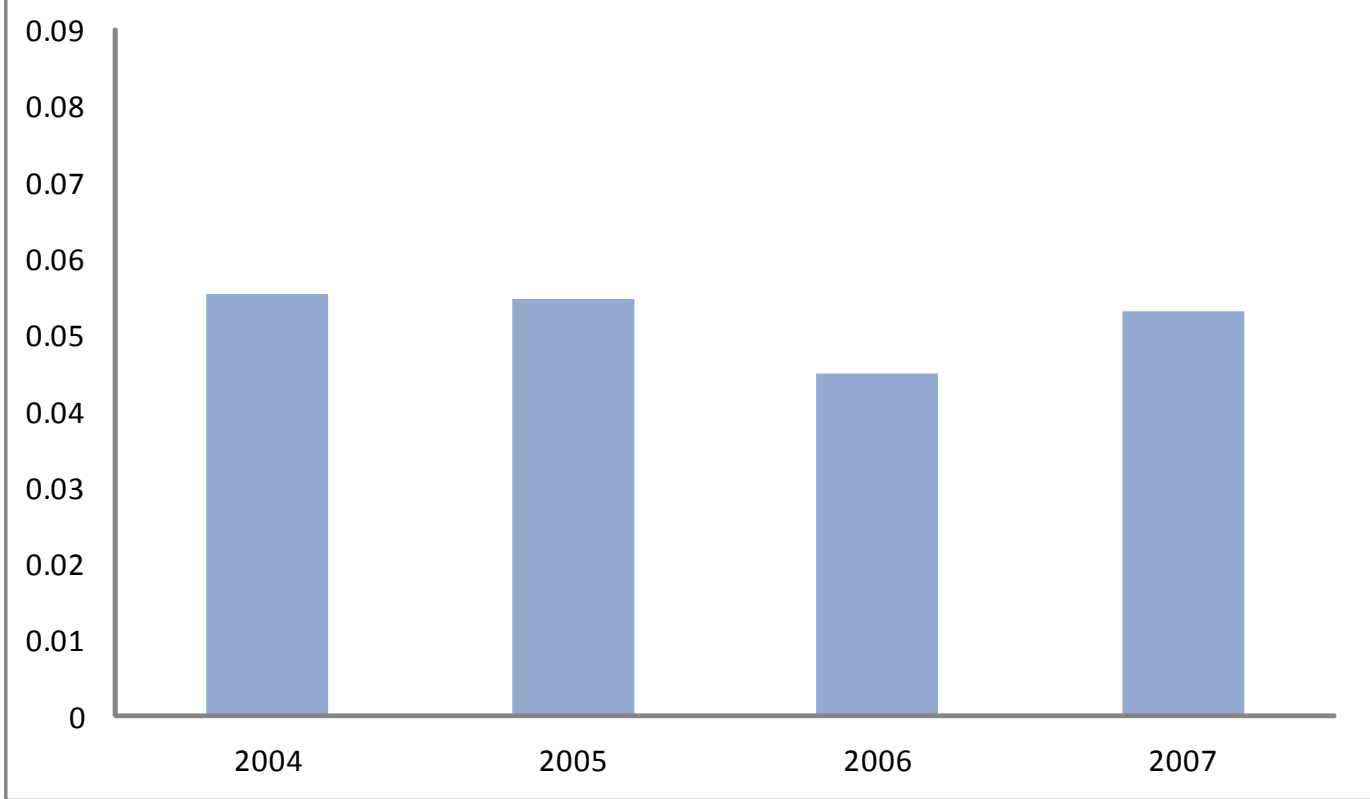

Note. - This figure reports the number of treated firms in each year as a percentage of the firms with an exclusive relationship with our bank for the two prior years for which the limit is not binding. 
Table 1: Variable Definitions and Descriptive Statistic

\begin{tabular}{|c|c|c|c|c|c|c|c|c|c|c|c|c|c|c|c|c|c|c|c|}
\hline \multirow{2}{*}{ Variable Names } & \multirow[t]{2}{*}{ Definition } & \multirow{2}{*}{\multicolumn{3}{|c|}{ Treated }} & \multicolumn{5}{|c|}{ Universe } & \multicolumn{5}{|c|}{ Treated(Match 1) } & \multicolumn{5}{|c|}{ Treated(Match 2) } \\
\hline & & & & $\mathrm{SD}$ & Mean & & Mediar & & SD & Mean & & Medic & & SD & Mean & & Mediar & & SD \\
\hline 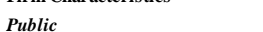 & \multicolumn{19}{|c|}{ Firm Characteristics } \\
\hline Firm Age & Number of years since the date of registration & 18.828 & 15.000 & 14.601 & 18.927 & & 15.000 & * & 16.003 & 20.483 & $*$ & 16.500 & **** & 13.870 & 21.251 & ** & 17.000 & $* * *$ & 14.047. \\
\hline Total Assets & Total assets of the firm (in 1,000 SEK) & 389,000 & 3,093 & $7,600,000$ & 224,000 & & 3,760 & $* * *$ & $3,910,000$ & 24,200 & & 3,006 & & 207,000 & 10,400 & & 2,890 & & 32,800 \\
\hline Asset Growth & Total assets at $\mathrm{t} /$ Total assets at $\mathrm{t}-12$ & 1.119 & 1.017 & 0.717 & 1.042 & **** & 1.009 & ** & 0.245 & 1.070 & & 1.028 & & 0.249 & 1.067 & & 1.036 & & 0.221 \\
\hline Tangible Assets to Total Assets & Tangible assets includes all fixed assets, accounts receivable, and inventories & 0.716 & 0.814 & 0.270 & 0.687 & *** & 0.772 & **** & 0.274 & 0.795 & *** & 0.866 & **** & 0.192 & 0.814 & $* * *$ & 0.870 & $* * *$ & 0.173 \\
\hline Cash Flow to Total Assets & Eeamings before interest and taxes / Total assets & 0.042 & 0.045 & 0.174 & 0.046 & & 0.052 & ** & 0.192 & 0.056 & *** & 0.051 & *** & 0.084 & 0.051 & *** & 0.050 & *** & 0.070 \\
\hline Total Debt to Total Assets & Includes all debt obligations, excluding unused credit lines and taxes & 0.428 & 0.424 & 0.297 & 0.431 & & 0.415 & & 0.273 & 0.471 & ** & 0.459 & $* * *$ & 0.218 & 0.507 & $* * *$ & 0.498 & $* * *$ & 0.206 \\
\hline Total Bank Debt to Total Assets & Includes all bank debt obligations, excluding unused credit lines & 0.274 & 0.212 & 0.249 & 0.259 & * & 0.195 & *** & 0.254 & 0.296 & & 0.250 & ** & 0.225 & 0.336 & *** & 0.307 & *** & 0.222 \\
\hline Probability of Default & Probability of default estimated by the main Swedish credit bureau & 3.106 & 1.200 & 5.876 & 2.773 & & 1.000 & *** & 6.336 & 1.805 & **** & 1.200 & & 2.295 & 1.816 & **** & 1.200 & & 2.347 \\
\hline External Rating & Takes values $1,2, \ldots .5$, where 1 indicates the worst and 5 the best rating & 3.193 & 3.000 & 1.118 & 3.322 & *** & 3.000 & **** & 1.089 & 3.300 & & 3.000 & & 0.852 & 3.280 & & 3.000 & & 0.835 \\
\hline Recent Repayment Problems & A dummy $=1$ if recent repayment problem with third parties, $=0$ otherwise & 0.032 & 0.000 & 0.177 & 0.021 & ** & 0.000 & ** & 0.142 & 0.000 & $* * *$ & 0.000 & **** & 0.000 & 0.000 & **** & 0.000 & **** & 0.000 \\
\hline \multicolumn{20}{|c|}{50} \\
\hline Internal Limit & Maximum amount the bank is willing to lend to the firm (in 1,000 SEK) & 29,200 & 1,046 & 230,000 & 21,100 & & 927 & $* * *$ & 182,000 & 10,200 & & 1,251 & & 81,200 & 5,627 & & 1,253 & & 19,300 \\
\hline Internal Limit to Total Assets & Intemal limit/ Total assets & 0.430 & 0.367 & 0.312 & 0.347 & ${ }_{* * *}$ & 0.295 & $* * *$ & 0.245 & 0.427 & & 0.396 & & 0.212 & 0.450 & & 0.421 & $* * *$ & 0.201 \\
\hline Distance to Limit & (Intermal limit- Outstanding bank debt - Unused credit lines) / Intemal limit & 0.135 & 0.048 & 0.191 & 0.115 & $* *$ & 0.021 & $* * *$ & 0.203 & 0.123 & & 0.048 & & 0.158 & 0.088 & **** & 0.037 & & 0.104 \\
\hline Loan Interest Rate (\%) & Interest rate on outstanding loans at the initial bank (in \%, annualized) & 6.418 & 6.600 & 2.201 & 6.117 & *** & 6.250 & $* * *$ & 2.347 & 6.521 & & 6.565 & & 1.750 & 6.607 & & 6.600 & & 1.609 \\
\hline Internal Rating & Takes values $1,2, \ldots . .5$, where 1 indicates the worst and 5 the best rating & 3.148 & 3.000 & 0.890 & 3.313 & *** & 3.000 & **** & 0.892 & 3.163 & & 3.000 & & 0.775 & 3.098 & & 3.000 & & 0.762 \\
\hline \multicolumn{20}{|l|}{ Relationship Characteristics } \\
\hline Multiple Relationships & A dummy $=1$ if a firm is borrowing from multiple banks, $=0$ otherwise & 0.000 & 0.000 & 0.000 & 0.305 & *** & 0.000 & **** & 0.460 & 0.000 & & 0.000 & & 0.000 & 0.000 & & 0.000 & & 0.000 \\
\hline Credit Concentration & Outstanding debt with the initial bank to total bank debt & 1.000 & 1.000 & 0.000 & 0.882 & **** & 1.000 & **** & 0.264 & 1.000 & & 1.000 & & 0.000 & 1.000 & & 1.000 & & 0.000 \\
\hline $\begin{array}{l}\text { Relationship Length } \\
\text { Outside Loan \& Limit } \\
\text { Adjustment }\end{array}$ & Number of years since the earliest observed credit product at the initial bank & 10.607 & 10.000 & 6.278 & 9.918 & *** & 9.000 & $* * *$ & 6.453 & 11.117 & & 10.500 & & 6.440 & 11.435 & * & 11.000 & * & 6.410 \\
\hline OutsideLoan & Outside loan (i.e., size of loan initiated at another bank) / Total assets $10-12$ & 0.179 & 0.055 & 0.523 & - & & - & & - & 0.125 & * & 0.045 & ** & 0.250 & 0.126 & & 0.046 & * & 0.269 \\
\hline Adjustment in the Internal Limit & [(Limitit0+12 - Limitto-12)/Total assets $50-12]$ for treated firms & -0.061 & -0.026 & 0.337 & - & & - & & - & -0.059 & & -0.026 & & 0.236 & -0.050 & & -0.026 & & 0.269 \\
\hline \multicolumn{20}{|c|}{ Collateral Information } \\
\hline FloatingCharge & A dummy $=1$ if initial bank's debt is secured with floating ch & 0.066 & 0.000 & 0.248 & - & & - & & - & 0.077 & & 0.000 & & 0.267 & 0.077 & & 0.000 & & 0.268 \\
\hline FloatingChargeValue & Value of floating charge assets (estimated by the bank)/Committed debt & 0.494 & 0.509 & 0.345 & - & & - & & . & 0.542 & & 0.547 & & 0.250 & 0.561 & & 0.598 & & 0.266 \\
\hline FloatingChargeVolatility & Three-year earnings volatility /three-year average assets (if floating charge=1) & 0.102 & 0.064 & 0.120 & - & & . & & - & 0.076 & & 0.059 & & 0.053 & 0.077 & & 0.070 & & 0.048 \\
\hline OtherCollateral & $\begin{array}{l}\text { A dummy }=1 \text { if the initial bank's debt is secured by any other type of collateral } \\
\text { with value greater or equal than } 80 \% \text { of the bank's outstanding debt }\end{array}$ & 0.170 & 0.000 & 0.376 & 0.227 & *** & 0.000 & ${ }^{* * *}$ & 0.419 & 0.200 & & 0.000 & & 0.401 & 0.198 & & 0.000 & & 0.400 \\
\hline Number of Firm & & & 991 & & & & 19,197 & & & & & 350 & & & & & 207 & & \\
\hline Number of Observations & & & 991 & & & & 51,164 & & & & & & & & & & 207 & & \\
\hline
\end{tabular}

Note. - We report the mean, median and standard deviation (SD) for the treated group, the universe, the matched treated groups after the first (Treated (Match 1)) and second matching procedure (Treated (Match 2)). The matching variables and procedure are in Table 2. *, **, and *** reported next to the mean and median values of the universe and matched treated groups indicate whether the corresponding values are statistically different relative to the treated group at the $10 \%, 5 \%$, and 1\% levels, respectively. Differences in means are assessed using the Student's t-test. Differences in medians are assessed using the Wilcoxon-

Mann-Whitney test for continuous variables and the Pearson's Chi-square test for categorical variables. 
Table 2: Definition of Matching Variables

\begin{tabular}{|c|c|c|c|c|}
\hline Matching Variables & Match 1 & Match 2 & \# & Possible Values and Definition \\
\hline \multicolumn{5}{|l|}{ Calendar Time } \\
\hline Month-Year & $\mathrm{X}$ & $\mathrm{X}$ & 45 & 2003:04 - 2006:12 \\
\hline \multicolumn{5}{|l|}{ Relationship Characteris tics } \\
\hline Multiple Relationships & $\mathrm{x}$ & $\mathrm{X}$ & 1 & both treated and control firms have a single lending relationship for at least one year prior to the beginning of the event window \\
\hline Credit Concentration & $\mathrm{X}$ & $\mathrm{X}$ & 1 & both treated and control firms at the beginning of the event window have a $100 \%$ of their bank debt at the initial bank \\
\hline \multicolumn{5}{|l|}{ Firm Characteristics } \\
\hline \multicolumn{5}{|l|}{ Public } \\
\hline Industry & $\mathrm{X}$ & $\mathrm{X}$ & 46 & Two digit NACE codes \\
\hline Firm Age & $\mathrm{X}$ & $\mathrm{X}$ & 2 & $=1$ if the firm is younger then 10 years, and zero otherwise \\
\hline Total Assets & $\mathrm{X}$ & $\mathrm{X}$ & 2 & $=1$ if the treated and control firms have similar total assets (using a $(-40 \%,+40 \%)$ window), and $=0$ otherwise \\
\hline Asset Growth & $\mathrm{X}$ & $\mathrm{X}$ & 2 & $=1$ if the treated and control firms have similar assets growth during (t0-24, t0-12) (using a $(-40 \%,+40 \%)$ window), and $=0$ otherwise \\
\hline Tangible Assets to Total Assets & $\mathrm{X}$ & $\mathrm{X}$ & 2 & $=1$ if the treated and control firms have similar tangible assets to total assets (using a $(-40 \%,+40 \%)$ window), and $=0$ otherwise \\
\hline Cash Flow to Total Assets & $\mathrm{X}$ & $\mathrm{X}$ & 2 & $=1$ if the treated and control firms have similar EBIT to total assets (using a $(-20 \%,+20 \%)$ window), and $=0$ otherwise \\
\hline Total Debt to Total Assets & $\mathrm{X}$ & $\mathrm{X}$ & 2 & $=1$ if the treated and control firms have similar total debt to total assets (using a $(-40 \%,+40 \%)$ window), and $=0$ otherwise \\
\hline Total Bank Debt to Total Assets & $\mathrm{X}$ & $\mathrm{X}$ & 2 & $=1$ if the treated and control firms have similar total bank debt to total assets (using a $(-40 \%,+40 \%)$ window), and $=0$ otherwise \\
\hline Probability of Default & $\mathrm{x}$ & $\mathrm{X}$ & 5 & (1-5) corresponding to a PD in the $[8.05 \%, 100 \%),[3.05 \%, 8.05 \%),[0.75 \%, 3.05 \%),[0.25 \%, 0.75 \%)$, and $[0,0.25 \%)$ range \\
\hline Recent Repayment Problems & $\mathrm{X}$ & $\mathrm{X}$ & 2 & $=1$ if the firm defaulted on any payments during the last 24 months \\
\hline \multicolumn{5}{|r|}{ 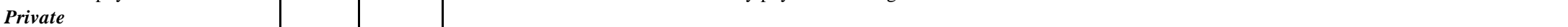 } \\
\hline Internal Limit & & $\mathrm{X}$ & 2 & $=1$ if the treated and control firms have a similar internal limit (using a $(-40 \%,+40 \%)$ window), and $=0$ otherwise \\
\hline Distance to Limit & & $\mathrm{X}$ & 2 & $=1$ if the treated and control firms have similar distance to limit (using a $(-40 \%,+40 \%)$ window), and $=0$ otherwise \\
\hline Loan Interest Rate & & $\mathrm{x}$ & 3 & $=1$ if the treated and control firms have similar loan interest rate (using a $(-40 \%,+40 \%)$ window), and $=0$ otherwise \\
\hline
\end{tabular}

$\mathrm{X} \quad 3 \quad=1$ if the treated and control firms have similar loan interest rate (using a $(-40 \%,+40 \%)$ window), and $=0$ otherwise

Note. - The table reports the variables included in the two matching procedures (Match 1 and Match 2), the number of possible values (\#) and a list of values for each matching variable. Variable definitions are in Table 1. 
Table 3: Firm Characteristics with and without a Floating Charge

\begin{tabular}{|c|c|c|c|c|c|c|c|c|}
\hline \multirow[t]{2}{*}{ Variable Names } & \multicolumn{3}{|c|}{ Floating Charge } & \multicolumn{5}{|c|}{ No Floating Charge } \\
\hline & Mean & Median & SD & Mean & & Median & & SD \\
\hline \multicolumn{9}{|l|}{ Firm Characteristics } \\
\hline \multicolumn{9}{|l|}{ Public } \\
\hline Firm Age & 12.938 & 11.500 & 8.858 & 21.948 & $* *$ & 17.000 & $* * *$ & 14.193 \\
\hline Total Assets & 11,800 & 2,583 & 21,800 & 10,300 & & 2,895 & & 33,600 \\
\hline Asset Growth & 0.968 & 0.998 & 0.180 & 1.076 & $*$ & 1.037 & & 0.222 \\
\hline Tangible Assets to Total Assets & 0.771 & 0.804 & 0.223 & 0.817 & & 0.870 & & 0.169 \\
\hline Cash Flow to Total Assets & 0.028 & 0.040 & 0.080 & 0.053 & & 0.051 & & 0.069 \\
\hline Total Debt to Total Assets & 0.518 & 0.510 & 0.209 & 0.506 & & 0.498 & & 0.206 \\
\hline Total Bank Debt to Total Assets & 0.322 & 0.211 & 0.268 & 0.337 & & 0.317 & & 0.219 \\
\hline Probability of Default & 1.881 & 1.850 & 1.442 & 1.811 & & 1.200 & & 2.409 \\
\hline External Rating ( $1-5,5$ best) & 3.188 & 3.000 & 0.911 & 3.288 & & 3.000 & & 0.831 \\
\hline Recent Repayment Problems & 0.000 & 0.000 & 0.000 & 0.000 & & 0.000 & & 0.000 \\
\hline \multicolumn{9}{|l|}{ Private } \\
\hline Internal Limit & 6,021 & 924 & 11,700 & 5,593 & & 1,294 & & 19,900 \\
\hline Internal Limit to Total Assets & 0.488 & 0.400 & 0.296 & 0.447 & & 0.429 & & 0.191 \\
\hline Distance to Limit & 0.118 & 0.033 & 0.129 & 0.085 & & 0.039 & & 0.102 \\
\hline Loan Interest Rate (\%) & 6.090 & 5.970 & 1.835 & 6.650 & & 6.650 & & 1.587 \\
\hline Internal Rating ( $1-5,5$ best) & 3.333 & 3.000 & 0.866 & 3.079 & & 3.000 & & 0.754 \\
\hline \multicolumn{9}{|l|}{ Relationship Characteristics } \\
\hline Relationship Length & 7.938 & 7.000 & 4.074 & 11.728 & $* *$ & 11.000 & $* *$ & 6.490 \\
\hline \multicolumn{9}{|l|}{ Outside Loan \& Limit Adjus tment } \\
\hline OutsideLoan & 0.133 & 0.046 & 0.316 & 0.118 & & 0.046 & & 0.199 \\
\hline Adjustment in the Internal Limit & -0.023 & -0.008 & 0.261 & -0.053 & & -0.027 & & 0.270 \\
\hline \multicolumn{9}{|l|}{ Collateral Information } \\
\hline OtherCollateral & 0.125 & 0.000 & 0.342 & 0.215 & & 0.000 & & 0.412 \\
\hline
\end{tabular}

Note. - We report the mean, median and standard deviation (SD) of the characteristics of firms with and without floating charge included in Match 2. Variable definitions are in Table $1 .{ }^{*}, * *$, and *** reported next to the mean and median values of the no floating charge group indicate whether the corresponding values are statistically different relative to the floating charge group at the $10 \%, 5 \%$, and $1 \%$ levels, respectively. Differences in means are assessed using the Student's t-test. Differences in medians are assessed using the Wilcoxon-Mann-Whitney test for continuous variables and the Pearson's Chi-square test for categorical variables. 
Table 4: Non-Exclusivity Externalities and the Size of the Outside Loan: Test of H1

\begin{tabular}{|c|c|c|c|c|}
\hline Dependent variable: [( Limit $_{0}+12$-Limitt ${ }_{0}-1$ & $\begin{array}{l}\text { otal Assets } \\
\text { (I) }\end{array}$ & $\begin{array}{c}\text { ated }-[(\text { Limi } \\
\text { (II) }\end{array}$ & $\begin{array}{c}\left.\operatorname{mit}_{0_{0}-12}\right) / \mathrm{To} \\
\text { (III) }\end{array}$ & $\begin{array}{l}\left.\mathrm{tSt}_{0}-12\right]_{\text {Contro }} \\
\text { (IV) }\end{array}$ \\
\hline & Match 1 & Match 1 & Match 2 & Match 2 \\
\hline Number of Observations (Matched Pairs) & 1,421 & 1,421 & 549 & 549 \\
\hline Number of Treated Firms & 350 & 350 & 207 & 207 \\
\hline Intercept & $\begin{array}{c}-0.066 * * * \\
(-4.176)\end{array}$ & $\begin{array}{c}-0.026 \\
(-1.416)\end{array}$ & $\begin{array}{c}-0.062 * * * \\
(-2.877)\end{array}$ & $\begin{array}{c}-0.014 \\
(-0.559)\end{array}$ \\
\hline OutsideLoan & & $\begin{array}{c}-0.335 * * * \\
(-3.384) \\
\end{array}$ & & $\begin{array}{c}-0.408^{* * *} \\
(-3.152) \\
\end{array}$ \\
\hline $\mathrm{R}^{2}$ & - & 0.040 & - & 0.060 \\
\hline
\end{tabular}

Note.- The table reports results from matched regressions relating the standardized response in the internal limit to a constant term (Columns (I) and (III)) and to OutsideLoan (i.e. the size of loan at another bank divided by total assets at $t_{0}-12$; Columns (II) and (IV)). Columns (I) and (II) report the results for the first matching procedure (Match 1) whereas columns (III) and (IV) those for the second procedure (Match 2). The definitions of all variables and matching procedures are provided in Tables 1 and 2, respectively. We weight each observation by one over the number of matched control firms for each treated firm. Tstatistics calculated on robust standard errors, clustered on a treated-firm level, are reported in parenthesis. $* * *, * *$, and * indicate significance at the $1 \%, 5 \%$, and $10 \%$ level, respectively. 
Table 5: Robustness Checks: Alternative Explanations and Additional Controls

\begin{tabular}{|c|c|c|c|c|c|c|c|c|c|c|}
\hline & (I) & (II) & (III) & (IV) & $(\mathrm{V})$ & (VI) & (VII) & (VIII) & (IX) & $(\mathrm{X})$ \\
\hline & Match 2 & Match 2 & Match 2 & Match 2 & Match 2 & Match 2 & Match 2 & Match 2 & Match 2 & Match 2 \\
\hline Number of Observations (Matched Pairs) & 344 & 344 & 339 & 339 & 549 & 549 & 46 & 46 & 201 & 201 \\
\hline Number of Treated Firms & 132 & 132 & 154 & 154 & 207 & 207 & 38 & 38 & 122 & 122 \\
\hline Intercept & $\begin{array}{c}0.002 \\
(0.226)\end{array}$ & $\begin{array}{c}0.008 \\
(0.763)\end{array}$ & $\begin{array}{c}-0.069 * * * \\
(-3.316)\end{array}$ & $\begin{array}{c}-0.007 \\
(-0.351)\end{array}$ & $\begin{array}{c}-0.063 * * * \\
(-2.907)\end{array}$ & $\begin{array}{c}-0.014 \\
(-0.587)\end{array}$ & $\begin{array}{l}-0.089 * \\
(-1.854)\end{array}$ & $\begin{array}{c}0.084 \\
(1.560)\end{array}$ & $\begin{array}{l}-0.068^{*} \\
(-1.958)\end{array}$ & $\begin{array}{c}-0.007 \\
(-0.181)\end{array}$ \\
\hline OutsideLoan & & $\begin{array}{c}-0.046 \\
(-1.105)\end{array}$ & & $\begin{array}{c}-0.610 * * * \\
(-6.471)\end{array}$ & & $\begin{array}{c}-0.403 * * * \\
(-3.079)\end{array}$ & & $\begin{array}{c}-1.719 * * * \\
(-3.572)\end{array}$ & & $\begin{array}{c}-0.435 * * * \\
(-2.870)\end{array}$ \\
\hline Fees to Total Assets & & & & & $\begin{array}{c}0.020 \\
(1.149) \\
\end{array}$ & $\begin{array}{c}0.005 \\
(0.281) \\
\end{array}$ & & & & \\
\hline $\mathrm{R}^{2}$ & - & 0.01 & - & 0.12 & 0.00 & 0.06 & - & 0.27 & - & 0.07 \\
\hline
\end{tabular}

Note. - The table reports results for Match 2. Columns (I) and (II) report results on reverse causality, where the dependent variable is the standardized response one year

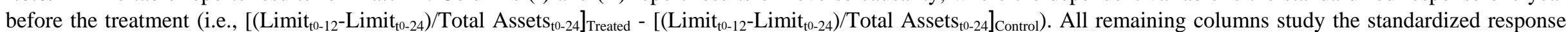

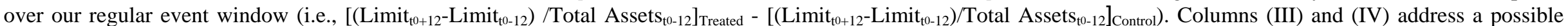
omitted variable bias, where specifications are estimated using the sub-sample of firms whose condition did not deteriorate during the event window (i.e., firms for which the probability of default at $\mathrm{t}_{0}+12$ is smaller than the probability of default at $\mathrm{t}_{0}-12$ and have no repayment problems during the event window). Columns (V) and (VI) display results on rent extraction by including the ratio of fees to total assets as an explanatory variable. In Columns (VII) and (VIII) we require that between $\mathrm{t}_{0}-12$ and $\mathrm{t}_{0}$ the matched control firm got an inside loan of similar size to the treated firm's outside loan to control for different investment opportunities. Finally, in Columns (IX) and (X) we add relationship length as an additional matching variable in Match 2 (we match using a +/- 3 years window). We weight each observation by one over the number of matched control-group firms for each treated firm. T-statistics calculated on robust standard errors, clustered on a treated-firm level, are reported in parenthesis. $* * *, * *$, and $*$ indicate significance at the $1 \%, 5 \%$, and $10 \%$ level, respectively. 
Table 6: Non-Exclusivity Externalities and Protection of Initial Creditor's Claims: Test of H2

\begin{tabular}{|c|c|c|c|c|c|c|c|c|}
\hline Dependent & $\begin{array}{l}\text { le: [(Limitt } \\
\text { (I) }\end{array}$ & $\begin{array}{l}{ }^{+12-\text { Limit }_{t_{0}-1}} \\
\text { (II) }\end{array}$ & $\begin{array}{c}\text { /Total Ass } \\
\text { (III) }\end{array}$ & $\begin{array}{l}\text { ts }_{t_{0}-12} \text { Treate } \\
\text { (IV) }\end{array}$ & $\begin{array}{l}-\left[\left(\text { Limit }_{0}+\right.\right. \\
\text { (V) }\end{array}$ & $\begin{array}{c}2-\text { Limit }_{0}-12 \\
\text { (VI) }\end{array}$ & $\begin{array}{c}\text { Total Ass } \\
\text { (VII) }\end{array}$ & $\begin{array}{c}\left.\mathrm{t}_{0}-12\right]_{\text {Control }} \\
\text { (VIII) }\end{array}$ \\
\hline & Match 1 & Match 1 & Match 1 & Match 1 & Match 2 & Match 2 & Match 2 & Match 2 \\
\hline Number of Observations (Matched Pairs) & 1421 & 1421 & 1421 & 1421 & 549 & 549 & 549 & 549 \\
\hline Number of Treated Firms & 350 & 350 & 350 & 350 & 207 & 207 & 207 & 207 \\
\hline Intercept & $\begin{array}{c}-0.027 \\
(-1.410)\end{array}$ & $\begin{array}{c}-0.027 \\
(-1.428)\end{array}$ & $\begin{array}{c}-0.022 \\
(-1.032)\end{array}$ & $\begin{array}{c}-0.023 \\
(-1.017)\end{array}$ & $\begin{array}{c}-0.013 \\
(-0.509)\end{array}$ & $\begin{array}{c}-0.013 \\
(-0.515)\end{array}$ & $\begin{array}{c}-0.011 \\
(-0.395)\end{array}$ & $\begin{array}{c}-0.011 \\
(-0.373)\end{array}$ \\
\hline OutsideLoan & $\begin{array}{c}-0.374 * * * \\
(-3.803)\end{array}$ & $\begin{array}{c}-0.374 * * * \\
(-3.810)\end{array}$ & $\begin{array}{c}-0.323 * * * \\
(-2.662)\end{array}$ & $\begin{array}{c}-0.373^{* * *} \\
(-3.000)\end{array}$ & $\begin{array}{c}-0.496 * * * \\
(-4.359)\end{array}$ & $\begin{array}{c}-0.496 * * * \\
(-4.348)\end{array}$ & $\begin{array}{c}-0.377^{* *} \\
(-2.569)\end{array}$ & $\begin{array}{c}-0.482 * * * \\
(-3.584)\end{array}$ \\
\hline OutsideLoan $x$ FloatingCharge & $\begin{array}{l}0.328^{*} \\
(1.847)\end{array}$ & & & $\begin{array}{l}0.327^{*} \\
(1.692)\end{array}$ & $\begin{array}{c}0.515 * * * \\
(3.614)\end{array}$ & & & $\begin{array}{c}0.500 * * * \\
(3.137)\end{array}$ \\
\hline FloatingCharge & $\begin{array}{c}0.029 \\
(0.435)\end{array}$ & & & $\begin{array}{c}0.025 \\
(0.363)\end{array}$ & $\begin{array}{c}0.053 \\
(0.564)\end{array}$ & & & $\begin{array}{c}0.051 \\
(0.537)\end{array}$ \\
\hline OutsideLoan x FloatingChargeValue & & $\begin{array}{c}1.157 * * * \\
(4.226)\end{array}$ & & & & $\begin{array}{c}1.437 * * * \\
(4.758)\end{array}$ & & \\
\hline FloatingChargeValue & & $\begin{array}{c}-0.015 \\
(-0.094)\end{array}$ & & & & $\begin{array}{c}-0.045 \\
(-0.192)\end{array}$ & & \\
\hline OutsideLoan $x$ FloatingChargeVolatility & & $\begin{array}{c}-8.382 * * * \\
(-2.757)\end{array}$ & & & & $\begin{array}{l}-8.100 * \\
(-1.849)\end{array}$ & & \\
\hline FloatingChargeVolatility & & $\begin{array}{c}0.846 \\
(0.915)\end{array}$ & & & & $\begin{array}{c}1.203 \\
(0.748)\end{array}$ & & \\
\hline OutsideLoan $x$ OtherCollateral & & & $\begin{array}{c}-0.024 \\
(-0.635)\end{array}$ & $\begin{array}{c}-0.024 \\
(-0.606)\end{array}$ & & & $\begin{array}{c}-0.007 \\
(-0.140)\end{array}$ & $\begin{array}{c}-0.007 \\
(-0.145)\end{array}$ \\
\hline OtherCollateral & & & $\begin{array}{c}-0.033 \\
(-0.189) \\
\end{array}$ & $\begin{array}{c}0.018 \\
(0.102) \\
\end{array}$ & & & $\begin{array}{c}-0.168 \\
(-0.774) \\
\end{array}$ & $\begin{array}{c}-0.064 \\
(-0.306) \\
\end{array}$ \\
\hline $\mathrm{R}^{2}$ & 0.04 & 0.05 & 0.04 & 0.05 & 0.08 & 0.09 & 0.06 & 0.08 \\
\hline
\end{tabular}

Note.- The table reports results from matched regressions relating the standardized response in the internal limit to a set of explanatory variables. Columns (I) to (IV) report the results for the first matching procedure (Match 1) whereas columns (V) to (VIII) report the corresponding results for the second matching procedure (Match 2). The definitions of all variables are provided in Table 1 . We weight each observation by one over the number of matched control-group firms for each treated firm. T-statistics calculated on robust standard errors, clustered on a treated-firm level, are reported in parenthesis. $* * *$, **, and * indicate significance at the $1 \%$, $5 \%$, and $10 \%$ level, respectively. 